\title{
Pelatihan Inovasi Media Pembelajaran Literasi dan Numerasi Antikorupsi dalam Kondisi Darurat Covid-19 di TK ABA Komplek Masjid Perak Prenggan
}

\author{
Anti-Corruption Literacy and Numerical Learning Media Innovation Training in Covid-19 \\ Emergency Conditions at ABA Kindergarten, Perak Prenggan Mosque Complex
}

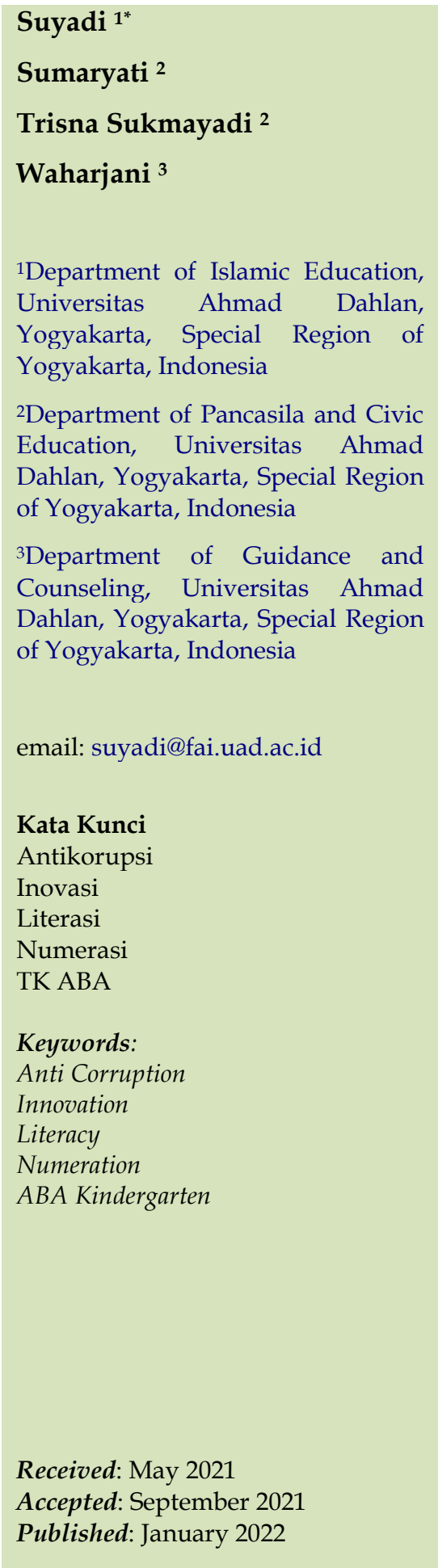

\begin{abstract}
Abstrak
Merebaknya kasus korupsi dana COVID-19 dari tingkat Desa, Kabupaten hingga Kementerian, berimplikasi langsung terhadap angka kematian, terlebih lagi anak usia dini mencapai $43,7 \%$ dari total kematian anak di masa COVID-19 atau 0,85\% dari total kematian terkonfirmasi positif. Numerasi dan literasi sebagai kompetensi minimum siswa telah banyak dibahas, namun literasi dan numerasi yang spesifik bidang antikorupsi belum banyak dipahami baik guru maupun siswa. Program Pemberdayaan Masyarakat (PPM) bertujuan meningkatkan tingkat keberdayaan literasi dan numerasi kelompok mitra melalui pelatihan inovasi media pembelajaran antikorupsi. Kelompok mitra PPM adalah TK ABA Komplek Masjid Perak Kotagede Yogyakarta yang terdiri dari 20 guru berpendidikan S1. Pelaksanaan PPM dilakukan sepanjang April hingga Juni 2021 secara daring. Metode pelaksanaan adalah sosialisasi, pelatihan, dan pendampingan. Teknik analisis data dikukan dengan mengukur tingkat keberdayaan mitra di bidang literasi dan numerasi antikorupsi. Hasil PPM menunjukkan bahwa peningkatan kompetensi literasi dan numerasi antikorupsi dalam bentuk cerita anak baru sampai pada tahap inovatif dan kreatif namun belum sampai pada berbasis teknologi digital. Hal ini disebabkan karena pelatihan daring di masa COVID-19 tidak memungkinkan menggunakan laboratorium multimedia interaktif sebagai perangkat literasi dan numerasi cerita anak berbasis teknologi digital. Meski demikian, hasil PPM ini telah mengubah pembelajaran literasi dan numerasi antikorupsi di masa pandemi COVID-19 menjadi lebih menyenangkan sehingga dapat mengurangi risiko stres dan cemas pada anak-anak serta berpotensi meningkatkan imunitas.
\end{abstract}

\begin{abstract}
The outbreak of corruption cases of COVID-19 funds from the Village, Regency to Ministry level, has direct implications for the death rate, especially early childhood, which reached $43.7 \%$ of total child deaths during the COVID-19 period or $0.85 \%$ of total deaths confirmed positive. Numeration and literacy as the minimum competencies of students have been widely discussed. However, literacy and numeracy specific to the field of anti-corruption have not been widely applied by both teachers and students. This Community Empowerment Program aims to increase the literacy and numeracy empowerment of partner groups through anticorruption learning media innovation training. This PPM partner group is TK ABA Komplek Masjid Perak Kotagede Yogyakarta which consists of 20 teachers with undergraduate education. Data analysis techniques are used to measure the level of empowerment of partners in the anti-corruption literacy and numeracy fields. The Community Empowerment results show that improving anti-corruption literacy and numeracy competencies in children's stories have only reached the innovative and creative stages but have not yet reached digital technology-based. This is because online training during the Covid-19 era did not support interactive multimedia laboratories as literacy tools and children's numeracy stories based on digital technology. Community Empowerment Program results have changed the learning of anti-corruption literacy and numeracy during the COVID-19 pandemic to be more enjoyable to reduce the risk of stress and anxiety in children and increase immunity.
\end{abstract}




\section{PENDAHULUAN}

Merebaknya kasus korupsi dana COVID-19 mulai dari tingkat desa, Kabupaten hingga Kementerian, berimplikasi langsung terhadap angka fatality rate. Korban kematian di masa COVID-19 tertinggi justru terjadi pada anak usia dini, yakni 43,7\% dari total kematian anak di masa COVID-19 atau 0,85\% dari total kematian terkonfirmasi COVID-19. Anak-anak tersebut meninggal dunia bukan karena terpapar positifCOVID-19, melainkan karena ketakutan, kecemasan (Ju et al., 2021), depresi, stress, trauma sosial (Boyraz et al., 2020; Miu et al., 2020), hingga gangguan kesehatan mental (Kusumaningrum et al., 2021; Jaspal \& Lopes, 2020). Bahkan, penelitian yang dilakukan Standish (2021) serta Thakur dan Jain (2020) menunjukkan bahwa 70\% para pasien COVID-19 yang isolasi mandiri beresiko tinggi bunuh diri.

Tingginya kematian anak-anak usia dini di masa COVID-19 disebabkan karena perluasan perilaku koruptif sebagaimana dijelaskan Mietner, seperti melanggar protokol kesehatan dan sikap orang tua terhadap anak yang cenderung anarkis. Hal ini dipicu oleh beban psikologis orang tua yang di satu sisi sedang bekerja dari rumah namun di sisi lain harus mendampingi anak-anak belajar di rumah. Kondisi ini masih diperparah dengan perilaku koruptif guru yang mengajar online hanya memberi tugas melalui aplikasi WhatsApp, padahal WhatsApp dipegang sepenuhnya oleh orang tua. Akibatnya, hampir setiap hari terjadi konflik anak dan orang tua sehingga berimplikasi terhadap meningkatnya kecemasan, ketakutan, depresi, dan trauma masal.

Hodgkinson dan Ali menyatakan bahwa korupsi di tengah pandemi COVID-19 mengalami perluasan bentuk dan kasus, tidak sebatas tujuh jenis korupsi sebagaimana yang dirumuskan KPK (Sumaryati et al., 2019), melainkan mencakup pelanggaran terhadap protokol kesehatan (Ali et al., 2021), penyebaran informasi hoax, menebar teror menakutkan (Qc, 2020), dan tindakan kompulsif baik yang merugikan diri sendiri dan orang lain (Aardema, 2020). Padahal, Chaudhry menyatakan bahwa perilaku koruptif di masa COVID-19 berimplikasi langusng terhadap meningkatnya jumlah kematian korban terdampak COVID-19 (Ali et al., 2021).

Penyebab utama merajalelanya korupsi dana COVID-19, termasuk perilaku koruptif di masa COVID-19 adalah minimnya pencegahan korupsi melalui literasi dan numerasi tentang antikorupsi itu sendiri. Hal ini diperkuat dengan Indeks Persepsi Korupsi Indonesia yang masih sangat rendah, dan merosot lagi pada tahun 2020 sebesar tiga point dari tahun sebelumnya, yakni dari 40 (2019) menjadi 37 (skala 100) pada tahun 2020 (Suyatmoko \& Nicola, 2021). Penelitian Suyadi et al. (2020a) juga menunjukkan bahwa pencegahan korupsi melalui literasi antikorupsi masih menjadi hal yang baru di lingkungan pendidikan, termasuk pendidikan anak usia dini. Oleh karena itu, literasi dan numerasi antikorupsi menjadi agenda mendesak di tengah pandemi COVID-19. Keberhasilan literasi antikorupsi akan berimplikasi terhadap masifnya gerakan pencegahan korupsi, termasuk perilaku koruptif di masa COVID-19. Dalam konteks pendidikan anak usia dini, gerakan literasi dan numerasi antikorupsi akan berimpliksi terhadap pengurangan risiko kematian anak usia dini di masa COVID19.

Kelompok mitra PPM ini adalah Taman Kanak-kanak Aisyiyah Bustanul Athfal Komplek Masjid Perak, Kelurahan Prenggan, Kemantren Kotagede, Kotamadya Yogyakarta. Kelompok mitra ini dipilih karena berada di kampung antikorupsi, yakni Prenggan yang dipilih KPK sebagai piloting desa antikorupsi di Indonesia sejak 2013 hingga sekarang (Suyadi, 2020a). Di samping itu, TK ABA Komplek Masjid Perak memiliki keunggulan berupa pojok baca literasi antikorupsi yang telah dikembangkan sejak 2019 (Suyadi et al., 2020a). Lebih dari itu, TK ABA Komplek Masjid Perak Prenggan juga memiliki komunitas relawan antikorupsi yang diorganisir ibu-ibu PKK (Rabi'e \& Nurhidayati, 2018). Dengan demikian pilihan kelompok mitra ini sangat berpotensi diberdayakan lebih optimal. Kelompok mitra saat ini berada di zona merah sebagaimana ditunjukkan Gambar 1. 


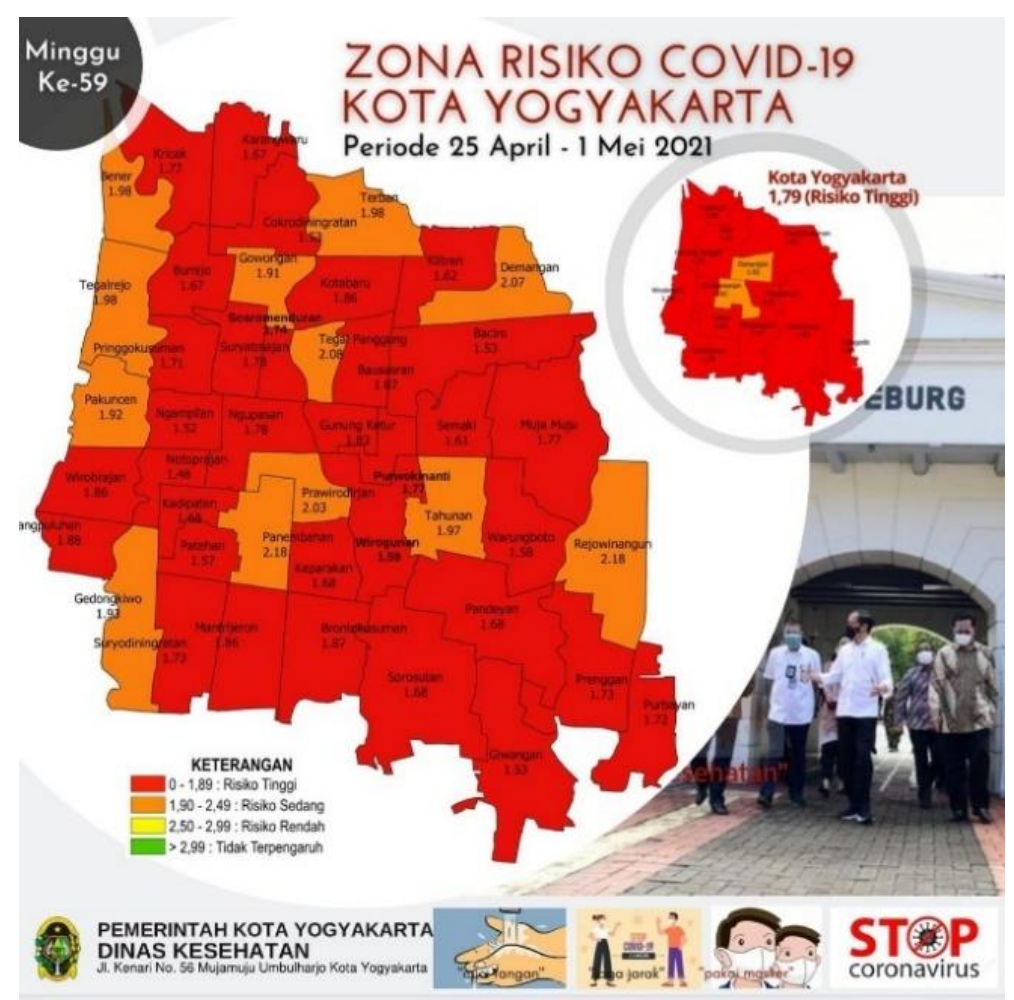

Gambar 1. Lokasi Pengabdian Masyarakat, Kelurahan Prenggan Zona Merah update 25 April sampai dengan 1 Mei 2021

Perwakilan Tim Pengabdi melakukan analisis situasi kepada kelompok mitra secara luring pada situasi melalui wawancara baik luring maupun daring Permasalahan mitra selama pandemi COVID-19 cukup banyak, seperti menurunnya Pendaftaran Siswa Baru, krisis keuangan sekolah karena banyak siswa yang cuti, kendala pembelajaran daring, dan lain sebagainya. Namun Tim Pengabdi memandang bahwa semua permasalahan tersebut adalah problematika umum di semua lembaga pendidikan, terlebih lagi Taman Kanak-kanak. Oleh karena itu, kami menginvestigasi permasalahan yang lebih krusial, aktual dan memiliki potensi untuk mengatasinya, yakni pendidikan antikorupsi di masa Pandemi COVID19. Pada tahun 2019, kelompok mitra telah mengembangkan pojok baca literasi antikorupsi, sehingga memungkinkan untuk dikembangkan. Gambar 2 menunjukkan analisis situasi yang dilakukan oleh perwakilan Tim Pengabdi dengan kelompok mitra Kepala Sekolah dan para Guru di TK ABA Komplek Masjid Perak.

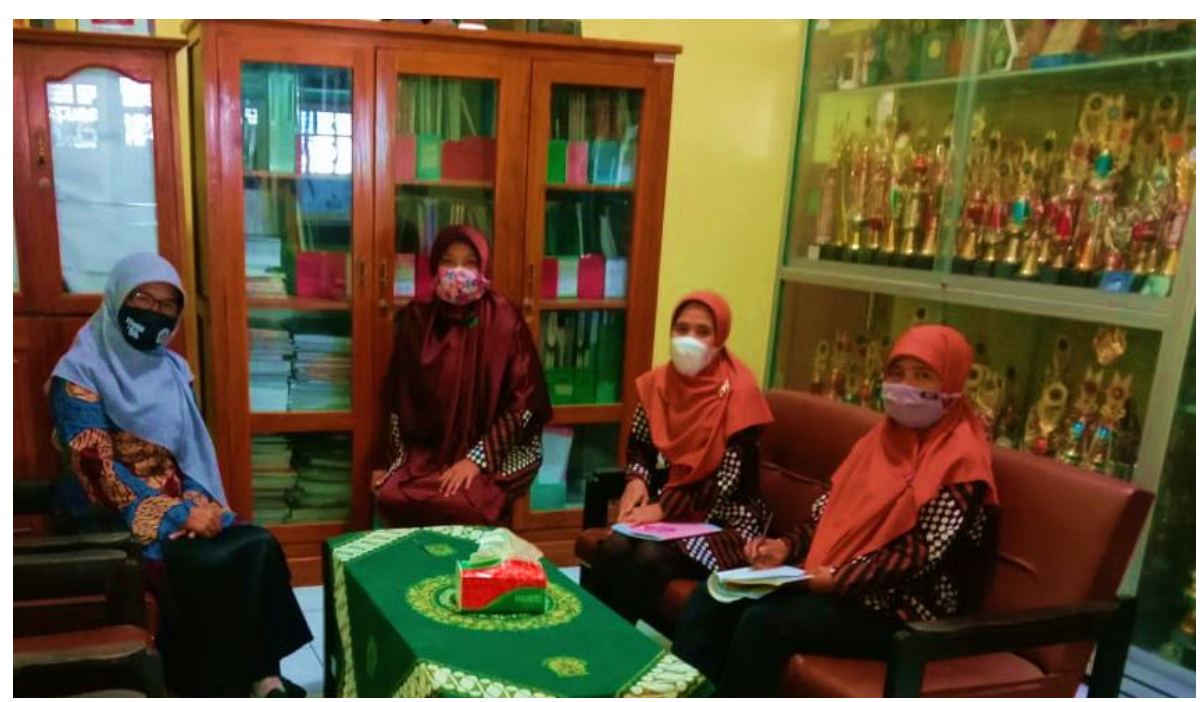

Gambar 2. Analisis situasi antara Tim Pengabdi dengan Kepala Sekolah dan para Guru TK ABA Komplek Masjid Perak Prenggan 
Hasil analisis menunjukkan bahwa keberadaan pojok baca literasi antikorupsi yang sudah ada selama ini masih didominasi oleh koleksi buku-buku dari luar. Belum ada satupun buku cerita karya guru TK ABA Komplek Masjid Perak. Padahal, sebagai sekolah Muhammadiyah yang berbasis pada gerakan amar ma'ruf nahi munkar dan tajdid TK ABA memiliki sumber inspirasi antikorupsi yang luar biasa. Bahkan, persyarikatan ini telah menerbitkan fikih antikorupsi yang di dalamnya terdapat ulasan sejarah korupsi di zaman Nabi Muhammad SAW (Anwar, 2006). Oleh karena itu, analisis situasi tersebut menghasilkan kesepakatan perlunya pengembangan pojok baca literasi antikorupsi.

Berdasarkan analisis situasi yang telah dilakukan, Tim Pengabdi menawarkan solusi terstruktur dan sistematis sesuai kompetensi tim pengabdi dan berbasis pada hasil-hasil penelitian Tim Pengabdi. Perlu diketahui bahwa Tim Pengabdi di samping akademisi juga Penyuluh Antikorupsi tersertifikasi oleh Lembaga Sertifikasi Kompetensi (LSP) Komisi Pemberantasan Korupsi (KPK). Di samping itu, riset-riset Tim Pengabdi yang sejalan dengan pendidikan antikorupsi sangat memadai diterapkan dalam pengabdian ini. Beberapa diantaranya yang dapat disebut di sini adalah Inovasi PAUD antikorupsi (Suyadi \& Sumaryati, 2020; Suyadi \& Ulfa, 2013), pendidikan antikorupsi dalam keluarga, sekolah dan masyarakat (Sumaryati et al., 2019), integrasi pendidikan antikorupsi dalam pembelajaran keagamaan Islam (Suyadi, 2019a), fikih kebencanaan di masa COVID-19 (Suyadi et al., 2020b), pengembangan pojok baca literasi antikorupsi di masa COVID-19 (Suyadi et al., 2020a), dan kesalehan konstitusional sebagai integrasi pendidikan antikorupsi dalam pembelajaran keagamaan Islam (Suyadi et al., 2019). Keseluruhan hasil-hasil penelitian Tim Pengabdi tersebut akan menjadi materi inti dalam pelatihan literasi dan numerasi antikorupsi. Dengan demikian, solusi terstruktur dan sistematis dalam pelatihan ini berbasis pada hasil-hasil penelitian yang sangat memadai. Dengan demikian, Tim Pengabdi memiliki kompetensi dan hasil penelitian yang sangat memadai untuk memberi solusi secara terstruktur dan sistematis atas permasalahan prioritas kelompok mitra, yakni TK ABA Komplek Masjid Perak Prenggan.

Dalam waktu beberapa tahun ke depan, pelatihan ini akan menghasilkan buku-buku cerita karya original guru yang diinspirasi dari kisah-kisah dalam Al-qur'an dan sunnah sebagai koleksi pojok baca literasi antikorupsi. Sesuai protokol kesehatan, semua bentuk kegiatan yang mengumpulkan banyak orang di zona merah tidak diperbolehkan. Oleh karena itu, PPM ini dilakukan secara daring, kecuali sesi pendampingan dan simulasi.

Berdasarkan analisis situasi tersebut, tujuan Pengabdian Masyarakat ini adalah mengembangkan tingkat keberdayaan kelompok mitra di bidang inovasi media pembelajaran literasi dan numerasi antikorupsi selama COVID-19. Tujuan ini mencakup pelatihan inovasi media pembelajaran literasi dan numerasi antikorupsi. Media literasi dan numerasi antikorupsi dispesifikkan pada penulisan buku cerita anak. Jadi buku cerita yang mengintegrasikan literasi dan numerasi, namun pesan moralnya dispesifikasikan pada pencegahan korupsi di tengah pandemi COVID-19.

Pengabdian ini berbeda dengan pengabdian masyarakat pada tahun sebelumnya, yakni pengembangan pojok baca literasi antikorupsi pada kelompok mitra yang sama (Suyadi et al., 2020a). PPM tersebut fokus pada rekayasa pojok literasi yang selama ini sudah ada menjadi pojok baca literasi antikorupsi. Rekayasa dilakukan pada aspek fisik, rak buku berbentuk tunas berintegritas dan isi koleksi buku bacaan anak bermuatan antikorupsi. Dengan demikian, PPM ini adalah program lanjutan dengan agenda yang berkesinambungan. Secara spesifik, perbedaan PPM ini dari pada tahun sebelumnya terletak pada karya inovatif kelompok mitra untuk mengisi rak buku pada pojok baca literasi antikorupsi. Selama ini pojok baca literasi antikorupsi berisi buku-buku karya penulis lain, terutama tim dari KPK. Dalam PPM ini, Tim Pengabdi ingin membekali kelompok mitra agar mampu menulis cerita sebagai media pendidikan antikorupsi untuk koleksi inti pojok baca literasi antikorupsi tersebut. Dengan demikian anak-anak akan mempunyai kompetensi minimum literasi dan numerasi dari karya-karya original gurunya sendiri.

Di samping berbeda dengan PPM pada tahun sebelumnya, PPM ini juga sangat berbeda dengan PPM sejenis lainnya di lokasi-lokasi pengdian yang lain. Sebagian besar pelatihan literasi dan numerasi masih umum, belum spesifik pada literasi dan numerasi antikorupsi secara khusus, terlebih lagi di masa pandemi COVID-19. Beberapa yang dapat disebutkan di sini adalah pelatihan literasi dan numerasi bagi anak-anak keluarga pra sejahtera di Papua (Siallagan et al., 2020), pelatihan literasi sains bagi anak usia dini di Purwakarta (Atika et al., 2019), penyusunan program literasi di SD/MI Sidoarjo (Wulandari et al., 2021), dan masih banyak lagi PPM literasi lain pada umumnya. Berdasarkan penelusuran program- 
program PPM terdahulu, hanya ada satu PPM di bidang literasi secara khusus, yakni literasi sains. Dengan demikian, seluruh PPM tentang literasi dan numerasi masih umum, belum spesifik pada literasi antikorupsi. Di samping itu, PPM tersebut tidak terkait langsung dengan masa pandemi COVID-19. Dengan demikian, novelty dari PPM ini literasi dan numerasi antikorupsi di masa pandemi COVID-19 secara terintegrasi dalam buku cerita.

\section{METODE}

Alat yang digunakan dalam pelatihan ini terdiri dari dua perangkat, yakni hardware dan software. Alat berupa hardware berupa laptop, LCD, dan pengeras suara. Sedangkan alat berupa software adalah aplikasi Zoom Meeting. Perangkat hardware lebih banyak digunakan oleh kelompok mitra di lokasi PPM, yakni TK ABA Komplek Masjid Perak. Mereka memiliki ruang multimedia ber-AC dengan perangkat keras secara memadai terdiri dari $\mathrm{LCD}$, pengeras suara dan lampu penerangan yang cukup. Sebagian guru (10 orang) berkumpul di ruang multimedia tersebut untuk mengikuti pelatihan literasi dan numerasi antikorupsi secara daring. Sedangkan 10 guru lainnya berada di tempat yang berbeda. Di masa pandemi COVID-19 aplikasi Zoom Meeting telah terbukti menjadi media yang efektif untuk berbagai kegiatan daring, seperti webinar, workshop, pelatihan, bahkan pengajian virtual (Dewi \& Putra, 2020). Oleh karena itu, aplikasi ini dipilih untuk menjadi media dalam PPM ini.

Adapun bahan yang digunakan dalam PPM ini adalah materi slide Power Point. Materi ini dicarikan dari hasil-hasil penelitian Tim Pengabdi sebagaimana disebutkan sebelumnya. Secara umum, bahan pelatihan ini terdiri dari materi pokok literasi dan numerasi, inovasi media pembelajaran, nilai-nilai antikorupsi, dan teknik penulisan cerita anak. Seluruh materi tersebut dikemas secara aktif dan interaktif, sehingga pelatihan daring berjalan efektif.

Selanjutnya, secara teknis pelatihan dilaksanakan secara tiga tahap. Tahap pertama adalah pelatihan daring yang dilaksanakan pada 4 Mei 2021. Di akhir pelatihan Tim Pengabdi memberikan tugas kepada para guru untuk membuat draf cerita anak untuk pengembangan literasi dan numerasi antikorupsi. Tahap dua adalah pendampingan penyelesaikan cerita anak secara luring dan satu per satu (one to one) yang dilaksanakan pada 18 Mei 2021. Tahap ketiga adalah finalisasi draf buku cerita anak bermuatan nilai-nilai antikorupsi. Pada tahap ini, setiap guru memperagakan atau mendemonstrasikan literasi dan numerasi antikorupsi berdasarkan buku cerita yang disusun. Dalam hal ini Tim Pengabdi memberikan koreksi dan masukan-masukan untuk kesempurnaan buku cerita anak sebagai media inovasi literasi dan numerasi antikorupsi.

\section{HASIL DAN PEMBAHASAN}

Hasil dan pembahasan Program Pengabdian Masyarakat ini disajikan dalam tiga temuan pokok. Pertama, deskrpsi hasil pelaksanaan pengabdian, kedua interpretasi dan pembahasan atau analisis, dan ketiga adalah diskusi dan dampak hasil pengabdian masyarakat. Ketiga hasil dan pembahasan tersebut diuraikan secara terperinci dalam uraian-uraian berikut:

Deskripsi hasil pengabdian

Kegiatan pengabdian Pada Masyarakat (PPM) dimulai pada Selasa 4 Mei 2021 secara daring menggunakan aplikasi Zoom Meeting. Tim Pengabdi membuat poster atau background sebagai sosialisasi kegiatan sebagaimana ditunjukkan gambar 3, yang berjudul “Pelatihan Inovasi Media Pembelajaran Literasi dan Numerasi Antikorupsi di Tengah Pandemi COVID-19 Pada Kelompok Mitra TK ABA Komplek Masjid Perak Prenggan Yogyakarta". Gambar 3 menjelaskan bahwa PPM tersebut diselenggarakan oleh Tim Pengabdi dari Universitas Ahmad Dahlan dengan pendanaan Kemendikbudristek, didukung oleh Pemerintah Desa Kelurahan Prenggan, Pimpinan Ranting Muhammadiyah dan Aisiyah, Komisi Pemberantasan Korupsi (KPK), Sahabat Integritas Jogja Istimewa (Persatuan Penyuluh Antikorupsi Yogyakarta), dan Relawan Antikorupsi Keluarga Jujur Bahagia Prenggan. 


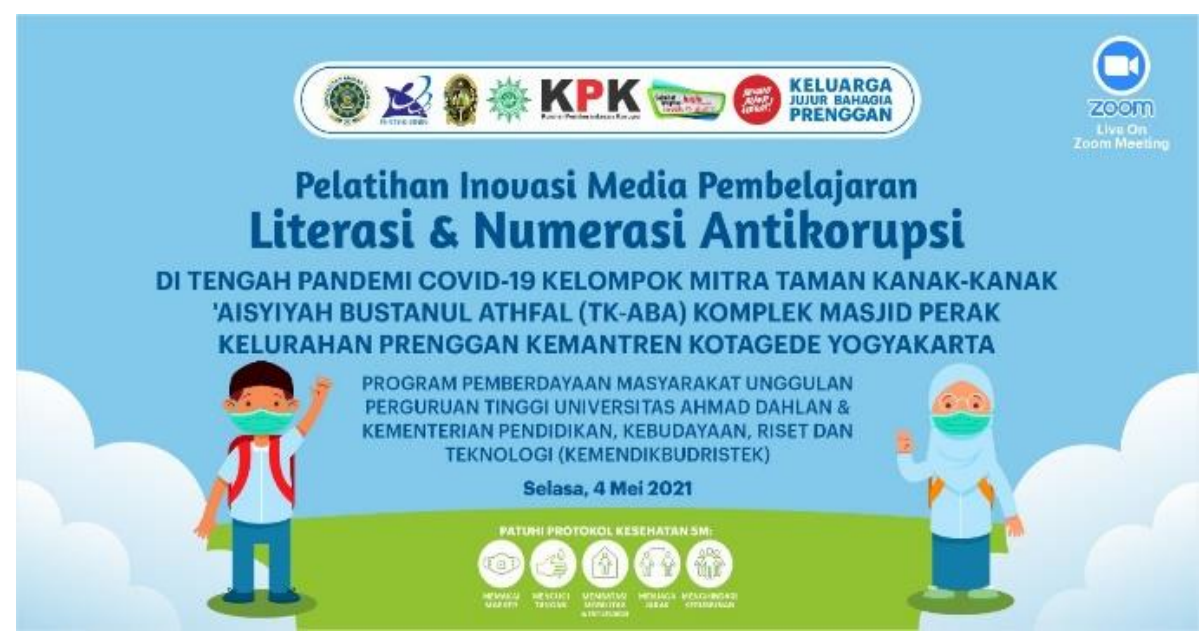

Gambar 3. Background Kegiatan PPM

Pada sesi opening ceremony, Tim pengabdi membuka kegiatan dengan upacara sakral, yakni pembacaan ayat-ayat AlQur'an tentang antikorupsi (QS. Al-Maidah [5]: 62-63), dilanjutkan dengan menyanyikan lagu wajib Indonesia Raya dan Sang Surya, kemudian sambutan oleh pihak LPPM UAD (diwakili ketua Tim Pengabdi), dilanjutkan dengan Sambutan Kepala TK ABA Komplek Masjid Perak Prenggan, dan terakhir adalah sambutan Pemilik TK Kemantren Kotagede. Suasana opening ceremony ditunjukkan Gambar 4.

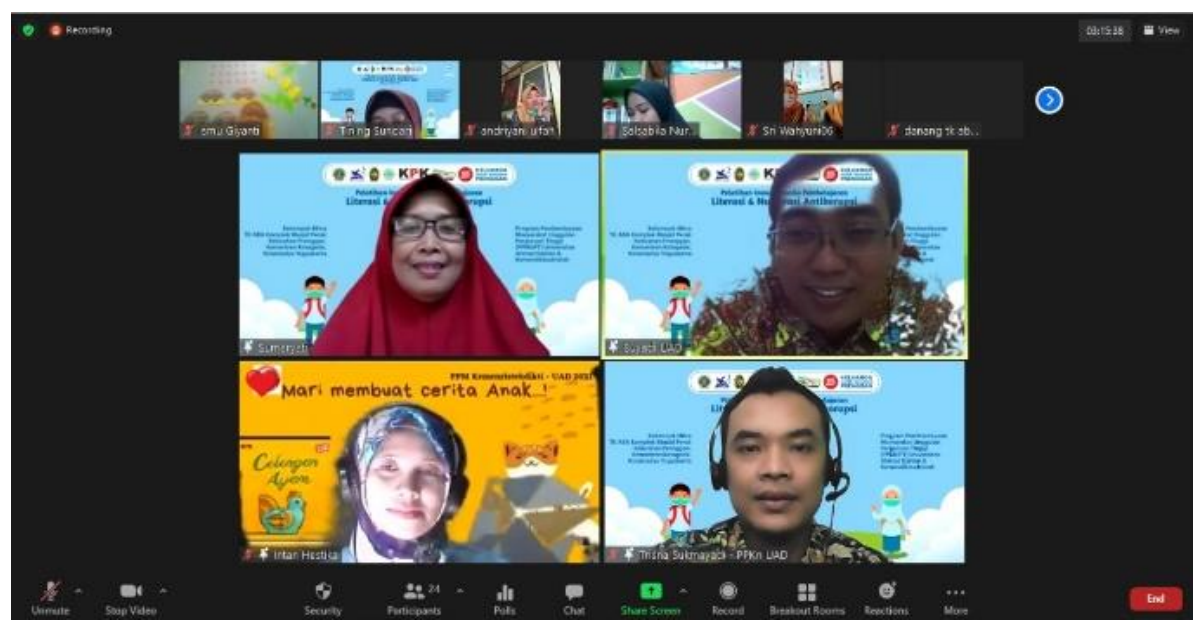

Gambar 4. Opening ceremony

Dalam sambutannya, Ketua Tim Pengabdi Menyampaikan bahwa kegiatan PPM ini tidak hanya satu hari ini melainkan terus berlanjut hingga target luaran tercapai, yakni draf buku cerita anak sebagai inovasi media pembelajaran literasi dan numerasi antikorupsi. Sedangkan Kepala TK ABA Komplek Masjid Perak menyampaikan antusiasmenya guru-guru dalam mengikuti PPM tersebut, karena menambah skill baik sikap, pengetahuan dan keterampilan. Adapun Pemilik TK Kemantren Kotagede dalam sambutannya menyampaikan bahwa TK ABA Komplek Masjid Perak mempunyai keunggulan khusus, yakni TK Antikorupsi, sehingga menjadi warna tersebut diantara TK lain di Kemantren Kotagede. Memasuki acara inti, Anggota Tim Pengabdi berbagi peran sebagai narasumber dan moderator serta host oleh mahasiswa yang terlibat. Dalam paparan materinya, Tim pengabdi menyampaikan dua materi pokok. Pertama, inovasi media pembelajaran literasi dan numerasi berbasis teknologi digital. Materi pokok tersebut mencakup elemen-elemen dalam digital storytelling sebagaimana ditunjukkan Gambar 5 dan alur pembuatan cerita berbasis teknologi digital sebagaimana ditunjukkan Gambar 6. 


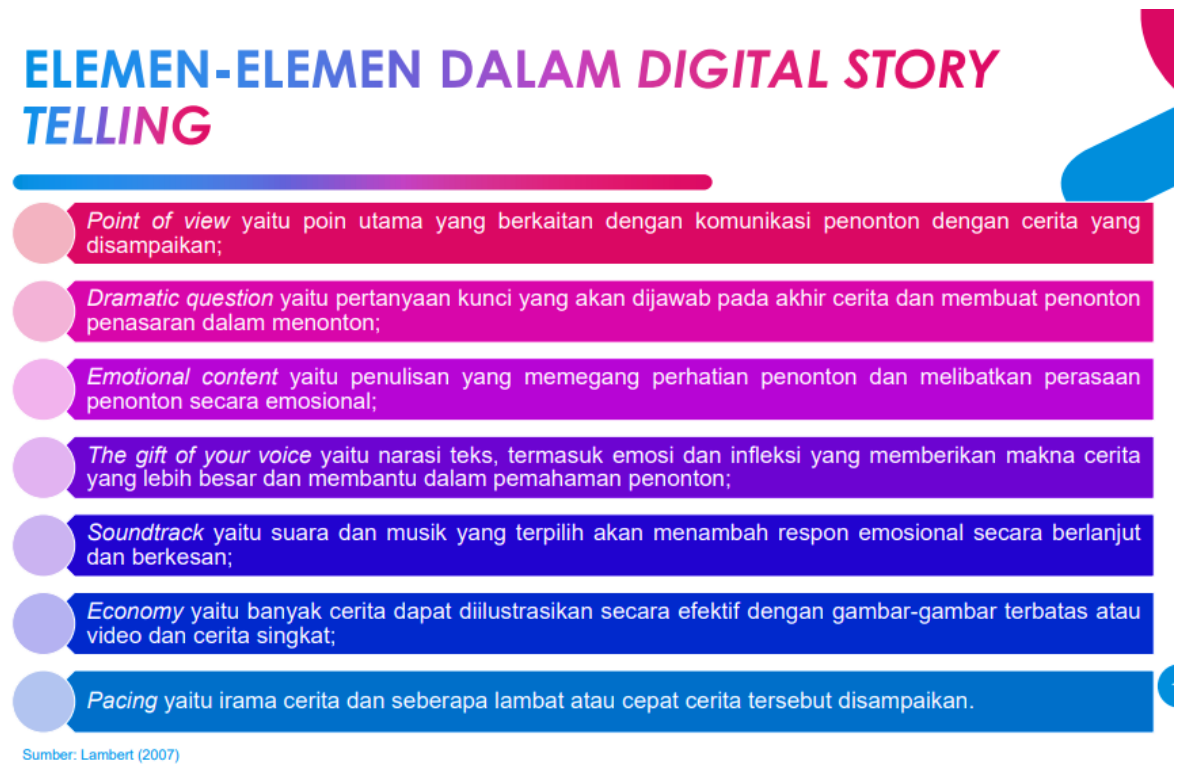

Gambar 5. Materi inovasi media pembelajaran literasi dan numerasi: elemen-elemen digital storytelling

\section{CARA MEMBUAT DIGITAL STORY TELLING}

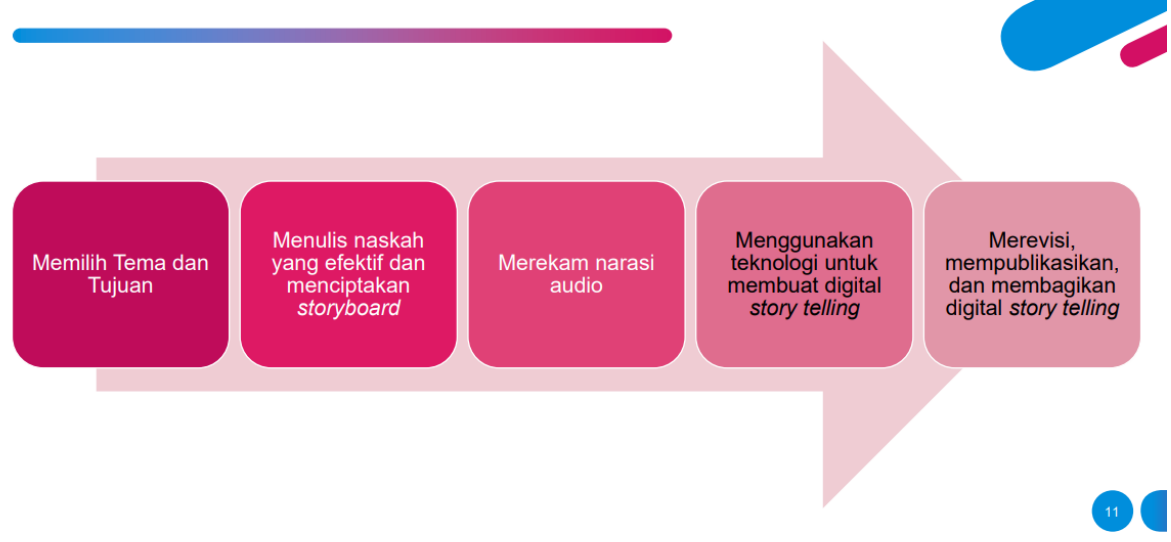

Gambar 6. Cara membuat digital storytelling

Gambar 5 menjelaskan cakupan inovasi media pembeajaran literasi dan numerasi yang terintegrasi dalam digital storytelling yang mencakup point of view, dramatic question, emotional content, the gift of your voice (narasi teks), soundtrack (suara dan musik), gambar, dan pacing atau irama cerita. Dengan demikian, buku cerita yang dikehendaki adalah buku cerita yang dapat disampaikan dengan berbagai media, termasuk media digital. Sedangkan Gambar 6 menjelaskan cara membuat digital storytelling yang meliputi: memilih tema dan tujuan, menulis naskah yang efektif dan menciptakan storyboard, merekam narasi audio, menggunakan teknologi untuk membuat digital storytelling, dan merevisi, digital storytelling.

Materi kedua, alur penulisan cerita anak bermuatan antikorupsi. Secara sistematis, alur penulisan buku cerita anak tersebut mencakup latar (dimana dan kapan cerita terjadi), tokoh (siapa saja dan bagaimana karakternya), inti cerita (pesan moral nilai-nilai antikorupsi), dan resolusi (akhir cerita). Alur cerita ini diambil dari hasil penelitian Tim Pengabdi tentang Kisah (storytelling) dalam pembelajaran anak usia dini perspektif neurosains (Suyadi, 2018a). Paparan materi inti tersebut sebagaimana ditampilkan Gambar 7. 


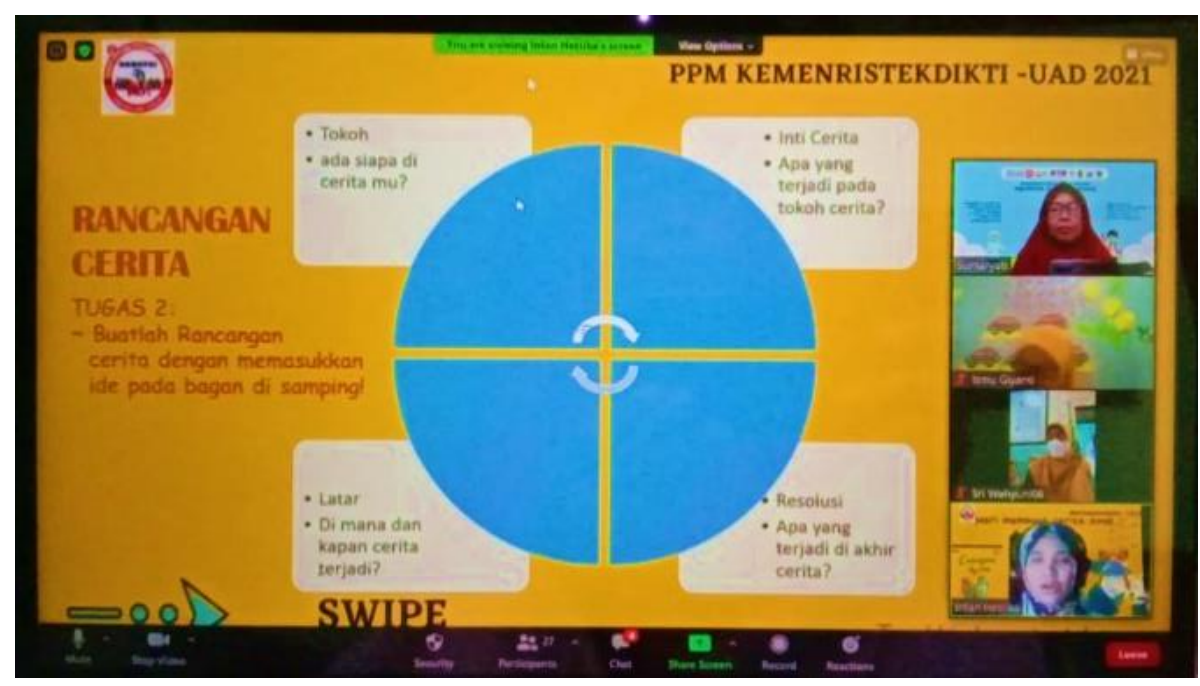

Gambar 7. Penyampaian materi dan penugasan

Gambar 7 merupakan salah satu slide paparan inti pelatihan inovasi media pembelajaran literasi dan numerasi antikorupsi. Pada akhir acara, Tim Pengabdi memberi dua tugas kepada kelompok mitra (guru-guru TK ABA Komplek Masjid Perak), yakni membuat resume materi hasil pelatihan pada hari tersebut dan memasukkan inti cerita pada template yang telah disiapkan sebelumnya. Tugas pertama dikumpulkan pada Selasa, 11 Mei dan tugas kedua dikumpulkan pada 25 Mei 2021. Pada hari tersebut, Tim Pengabdi akan melakukan pendampingan guna menyempurnakan tugas penulisan buku cerita anak sebagai inovasi media pembelajaran literasi dan numerasi antikorupsi. Pada akhir acara, Tim Pengabdi dan seluruh peserta, yakni guru-guru TK ABA Komplek Masjid Perak melakukan sesi foto bersama sebagaimana ditunjukkan Gambar 8.

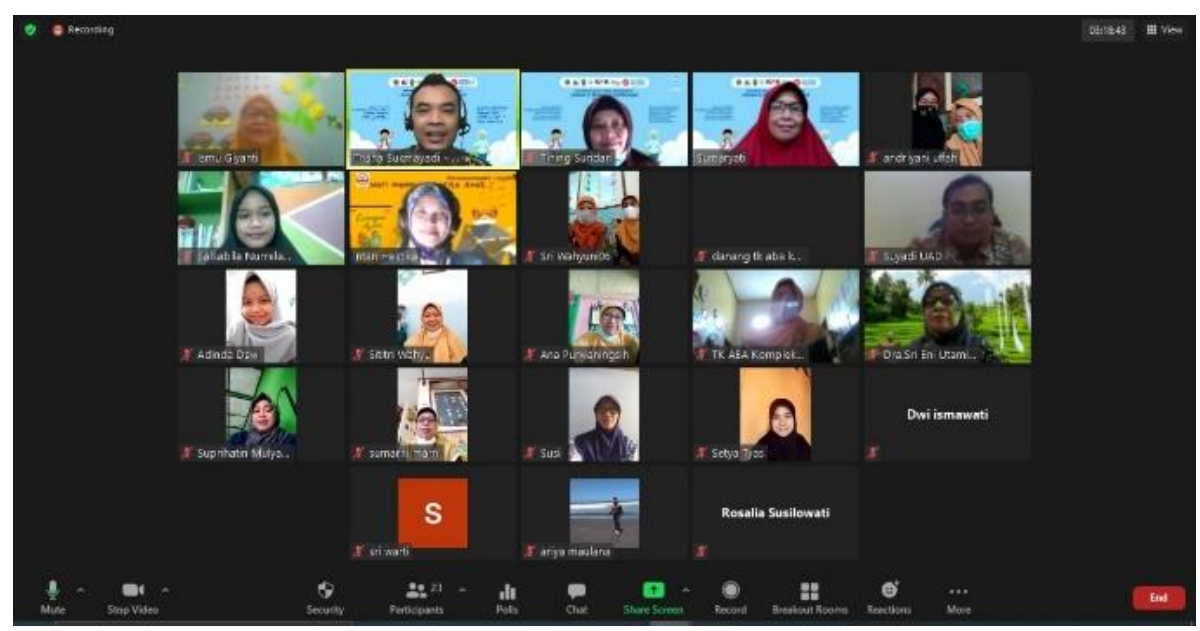

Gambar 8. Sesi foto closing ceremony

Sebagaimana tugas yang telah diberikan, pada tanggal 25 Mei para peserta mengumpulkan hasil unjuk kerjanya, yakni draf cerita anak bermuatan antikorupsi sebagai inovasi media pembelajaran literasi dan numerasi antikorupsi. Berikut ini salah satu judul buku cerita anak karya salah satu peserta pelatihan, berjudul, "Kaka Ayam Jago yang Sombong" sebelum pendampingan (Gambar 9). Buku cerita ini ditulis sejak mengikuti pelatihan dan diselesaikan pada Sabtu 20 Mei 2021 (16 hari). 


\section{Kaka Ayam Jago Yang Sombong}

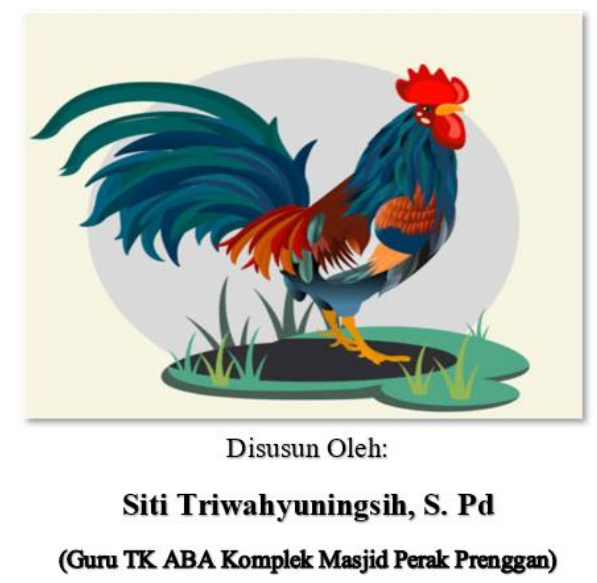

Gambar 9. Judul cerita anak sebelum pendampingan

Selanjutnya, buku cerita tersebut dikoreksi oleh Tim Pengabdi dan dilakukan revisi. Menurut penelitian Suyadi (2018b), judul di atas berkonotasi negatif karena menggunakan kata "Sombong." Oleh karena itu, dalam proses pendampingan, judulnya diubah menjadi pemberani sehingga redaksi judulnya menjadi “Kaka Ayam Jago yang Pemberani.” Judul ini disesuaikan dengan isi cerita yang mengisahkan bagaimana seorang ayam Jago bangun lebih pagi dan mencarikan makanan untuk ayam betina beserta anak-anaknya yang masih kecil. Gambar 10 adalah cover judul buku cerita anak yang telah selesai didampingi.

\section{Kaka Ayam Jago Yang Pemberani}

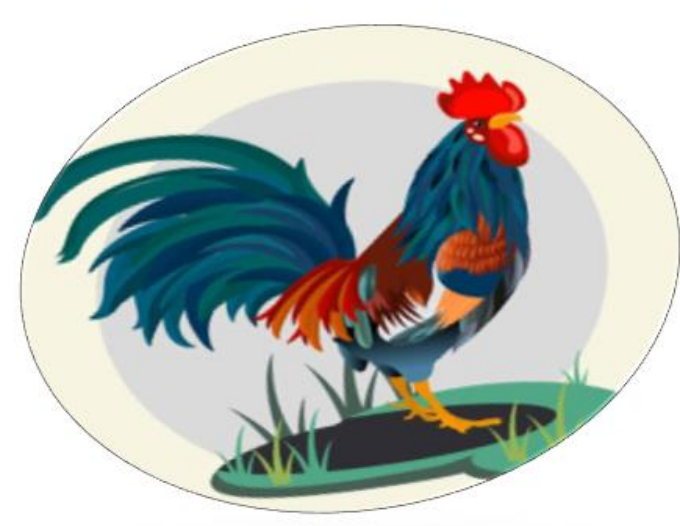

Disusun Oleh:

Siti Triwahyuningsih, S. Pd

(Guru TK ABA Komplek Masjid Perak Prenggan)

Gambar 10. Cover buku cerita anak "Kaka Jago Yang Pemberani" 
Berdasarkan hasil pendampingan, terjadi perbaikan yang signifikan, mulai dari judul hingga keseluruhan isi cerita. Perubahan tersebut mengacu pada hasil-hasil penelitian tentang storytelling dan prinsip-prinsip pengembangan karakter dalam pembelajaran anak usia dini (Suyadi, 2018c; 2016; 2014). Dengan demikian, PPM ini telah menghasilkan inovasi pembelajaran literasi dan numerasi antikorupsi dalam bentuk buku cerita.

Interpretasi, analisis dan pembahasan dilakukan dengan mengukur persentasi tingkat keberdayaan kelompok mitra dengan mengunakan pre test dan post test. Indikator penilaian berdasarkan tiga variabel, yakni literasi, numerasi dan nilainilai antikorupsi. Hasil pre test dan post test dibandingkan sehingga dapat diketahui tingkat keberdayaan kelompok mitra. Instrumen ini diadaptasi dari observasi antikorupsi koruptif yang dikembangkan oleh Suyadi (2019b). Tabel I merupakan analisis peningkatan tingkat keberdayaan mitra di bidang literasi, numerasi dan antikorupsi.

Tabel I. Peningkatan keberdayaan mitra

\begin{tabular}{lllc}
\hline \multicolumn{1}{c}{ Indikator } & \multicolumn{1}{c}{ Sebelum } & \multicolumn{1}{c}{ Sesudah } & Peningkatan (\%) \\
\hline Literasi & Pembelajaran membaca & Pembelajaran membaca trintegrasi dalam cerita & 30 \\
Numerasi & Pembelajaran menghitung & $\begin{array}{l}\text { Pembelajaran menghitung terintegrasi dalam } \\
\text { cerita (cerita berhitung) }\end{array}$ & 40 \\
Nilai-nilai antikorupsi & Mengetahui 9 nilai antikorupsi & $\begin{array}{l}\text { Menarasikan 9 nilai nilai antikorupsi dalam } \\
\text { sebuah cerita }\end{array}$ & 45 \\
\hline
\end{tabular}

Tabel I menunjukkan bahwa kelompok mitra mengalami peningkatan. Di bidang literasi, sebelum pelatihan mitra hanya mengajarkan membaca secara konvensional tetapi setelah pelatihan mereka mempunyai cerita sebagai media pembelajaran likterasi. Di bidang numerasi, sebelum pelatihan mereka mengenalkan angka dan bilangan secara langsung tetapi setelah mengikuti pelatihan mereka dapat mengintegrasikannya dalam cerita anak. Di bidang penguasaan nilai-nilai antikorupsi, sebelum mendapatkan pelatihan mereka hanya memahami 9 nilai antikorupsi, tetapi setelah mendapatkan pelatihan mereka mengemas 9 nilai antikorupsi tersebut dalam karakter masing-masing tokoh cerita. Dengan demikian, dapat dipahami bahwa PPM ini telah berhasil meningkatkan kemampuan kelompok mitra untuk membuat inovasi media pembelajaran literasi dan numerasi antikorupsi.

Perubahan pembelajaran literasi dan numerasi antikorupsi di atas berimplikasi terhadap kondisi psikologis anak, yang semula pembelajaran terkesan menegangkan menjadi pembelajaran yang penuh canda dan menyenangkan. Hal ini karena gaya cerita guru dapat dibuat variasi yang bermacam-macam sehingga tidak membosankan. Perubahan kondisi psikologis yang menyenangkan tersebut berimplikasi terhadap menurunnya kecemasan dan ketakutan anak-anak di masa pandemi COVID-19. Dengan kata lain, inovasi pembelajaran literasi dan numerasi antikorupsi pada anak usia dini melalui cerita yang menyenangkan berpotensi meningkatkan imunitas. Interpretasi ini dapat menjawab hasil-hasil penelitian yang menunjukkan bahwa selama pandemi COVID-19 anak-anak mengalami ketakutan, stres, trauma hingga gangguan mental, bahkan resiko bunuh diri (Ju et al., 2021; Boyraz et al., 2020; Miu et al., 2020; Kusumaningrum et al., 2021; Jaspal \& Lopes, 2020). Dengan menggunakan inovasi media pembelajaran literasi dan numerasi antikorupsi dalam bentuk cerita anak yang menyenangkan, maka hal tersebut dapat dihindari.

Pelatihan inovasi media pembelajaran literasi dan numerasi antikorupsi ini sangat berbeda dengan program-program pengabdian masyarakat sebelumnya, namun masih mempunyai kesamaan sebagai benang merah keberlanjutan. Dibandingan dengan PPM sebelumnya tentang profil pendidikan antikorupsi (Hanisa \& Suyadi, 2020), PPM ini merupakan spesifikasi dari PPM tersebut, yakni fokus pada media literasi dan numerasi. Dibandingkan dengan rekayasa pojok baca literasi antikorupsi (Suyadi et al., 2020a), maka PPM ini adalah isi atau koleksi untuk memperkaya pojok baca literasi antikorupsi tersebut. Dengan demikian, PPM ini memiliki keunikan tersendiri sebagai keberlanjutan dari PPM tahun sebelumnya.

Namun demikian, dari sisi peningkatan hasil pelatihan, harus diakui bahwa hasil PPM ini belum sebagaimana yang diharapkan, yakni menciptakan digital storytelling secara sempurna. Semuanya masih draf dan belum dilakukan penyatuan antara narasi cerita, efek audio dan visualisasi (Robin, 2008). Hal ini disebabkan karena dalam kondisi darurat COVID-19, praktik pembuatan digital storytelling yang membutuhkan laboratorium multimedia sulit dilakukan secara daring (Hanisa 
\& Suyadi, 2020; Chiodini, 2020; Pratama et al., 2020). Oleh karena karena itu, diperlukan pelatihan lanjutan berbasis luaran, dimana buku cerita anak hasil karya guru dikembangkan berbasis teknologi digital dan dipresentasikan menggunakan inovasi media pembelajaran yang lebih menyenangkan. Dengan demikian, tingkat keberdayaan mitra bisa mencapai 100\% dengan akuntabilitas yang terukur.

Dampak jangka panjang pelatihan ini adalah membangun karakter antikorupsi sekaligus meningkatkan kompetensi minimum siswa, yakni numerasi dan literasi serta survei karakter (Siallagan et al., 2020; Baro'ah, 2020; Widiyono et al., 2021). Dalam persektif neurosains, inovasi media pembelajaran literasi dan numerasi dalam bentuk cerita dapat membangun kecerdasan intelektual, emosional dan spiritual sekaligus (Suyadi, 2020b). Di samping itu, PPM ini juga sejalan dengan program Kemendikbudristek, yakni Merdeka Belajar. Tim Pengabdi yang melakukan PPM (intervensi sekolah penggerak) juga sejalan dengan kebijakan Kampus Merdeka. Dengan demikian dampak PPM ini sangat strategis untuk melakukan intervensi sekolah penggerak guna mengembangkan literasi dan numerasi terintegrasi dengan pengembangan karakter.

\section{KESIMPULAN}

Berdasarkan hasil pengabdian, interpretasi, analisis pembahasan dan dampak di atas, dapat disimpulkan bahwa pelatihan inovasi media pembelajaran literasi dan numerasi antikorupsi dalam bentuk buku cerita dapat mengubah pembelajaran yang semula membosankan menjadi menyenangkan. Literasi dan numerasi yang semula bagi anak terasa berat karena cognitif oriented, menjadi jauh lebih ringan karena diubah dalam bentuk cerita yang insipiratif dan menyenangkan. Perubahan kondisi psikologis dari membosankan dan menegangkan menjadi menyenangkan dapat mengurangi risiko stres dan kecemasan pada anak selama pembelajaran daring di masa COVID-19 sekaligus berpotensi meningkatkan imunitas anak. Lebih dari itu, PPM ini sejalan dengan kebijakan Merdeka Belajar untuk mengembangkan kompetensi minimum siswa dan survei karakter terintegtrasi secara holistik. Meskipun demikian, pelatihan daring di masa pandemi COVID-19 dipandang kurang maksimum karena praktik pembuatan digital storytelling sebagai inovasi media pembelajaran literasi dan numerasi antikorupsi yang mensyaratkan pengunaan laboratorium multimedia tidak dapat dilakukan secara daring. Oleh karena itu, diperlukan pelatihan-pelatihan berikutnya yang lebih ramah teknologi bagi mitra dan berbasis pada luaran sehingga tingkat kebedayaan mitra dapat terukur lebih akuntabel. Literasi dan numerasi antikorupsi perlu dikembangkan sebagai ciri khas dan keunggulan TK ABA Komplek Masjid Perak sebagai perintis TK Berintegritas atau TK Antikorupsi di Indonesia.

\section{UCAPAN TERIMA KASIH}

Tim Pengabdi, mengucapkan terimakasih kepada Kementerian Pendidikan, Kebudayaan Riset dan Teknologi (Kemendikbudristek) yang telah mendanai Program Pemberdayaan Masyarakat Unggulan Perguruan Tinggi skema Multi Tahunan ini secara penuh. Ucapan terimakasih juga kami sampaikan kepada LPPM Universitas Ahmad Dahlan yang telah mendukung terlaksananya Program Pemberdayaan Masyarakat ini. Ucapan terimakasih juga kami sampaikan kepada Kelurahan Prenggan, Kemantren Kotagede, Kotamadya Yogyakarta, khususnya TK ABA Komplek Masjid Perak Prenggan sebagai mitra pengabdian masyarakat ini.

\section{REFERENSI}

Aardema, F. 2020. COVID-19, obsessive-compulsive disorder and invisible life forms that threaten the self. Journal of Obsessive-Compulsive and Related Disorders. 26:100558. https://doi.org/10.1016/j.jocrd.2020.100558

Ali, T.O., Hassan, M., Hossain, N. 2021. The moral and political economy of the pandemic in Bangladesh: Weak states and strong societies during Covid-19. World Development. 137:105216. https://doi.org/10.1016/j.worlddev.2020.105216 
Anwar, S. 2006. Fikih Anti Korupsi Perspektif Ulama Muhammadiyah. Jakarta: Majelis Tarjih dan Tajdid Pimpinan Pusat Muhammadiyah.

Atika, A.R., Westhisi, S.M., Zahro, I.F. 2019. Pelatihan literasi sains untuk meningkatkan kemampuan berpikir ilmiah pada guru pendidikan anak usia dini. Jurnal Pendidikan Anak Usia Dini Undiksha. 7(3):266-271. http://dx.doi.org/10.23887/paud.v7i3.22297

Baro'ah, S. 2020. Kebijakan Merdeka Belajar Sebagai Peningkatan Mutu Pendidikan. Jurnal Tawadhu. 4(1):1063-1073

Boyraz, G., Legros, D.N., Tigershtrom, A. 2020. COVID-19 and traumatic stress: The role of perceived vulnerability, COVID19-related worries, and social isolation. Journal of Anxiety Disorders. 76:102307. https://doi.org/10.1016/j.janxdis.2020.102307

Chiodini, J. 2020. Online learning in the time of COVID-19. Travel Medicine and Infectious Disease. 34:101669. https://doi.org/10.1016/j.tmaid.2020.101669

Dewi, N.K., Putra, A.S. 2020. Efektifitas E-Dakwah dengan Menggunakan Aplikasi Zoom di Masa Pandemi Corona Virus (COVID 19). In Prosiding Seminar Nasional Kahuripan (SNapan) 2020. Kediri: Universitas Kahuripan Kediri

Hanisa, R.S., Suyadi. 2020. Dampak Pembelajaran Daring Terhadap Perilaku-Perilaku Religius Di Tengah Situasi Social Distancing Akibat Pandemi Covid-19. Al Ulya : Jurnal Pendidikan Islam. 5(2):226-238. https://doi.org/10.36840/ulya.v5i2.287

Jaspal, R., Lopes, B. 2020. Fear, social isolation and compulsive buying in response to COVID-19 in a religiously diverse UK sample. Mental Health, Religion and Culture. 22(23):427-442. https:/ /doi.org/10.1080/13674676.2020.1784119

Ju, Y., Chen, W., Liu, J., Yang, A., Shu, K., Zhou, Y., et al. 2021. Effects of centralized isolation vs. home isolation on psychological distress in patients with COVID-19. Journal of Psychosomatic Research. 143:110365. https://doi.org/10.1016/j.jpsychores.2021.110365

Kusumaningrum, S., Siagian, C., Beazley, H. 2021. Children' s Geographies Children during the COVID-19 pandemic: children and young people's vulnerability and wellbeing in Indonesia. Children's Geographies. 0(0):1-11. https://doi.org/10.1080/14733285.2021.1900544

Miu, A.S., Cheung, C., Tsang, K.K.Y., Chan, B.S.B., Poon, L., Fung, I.C. 2020. Broader trauma: Considerations for COVID-19 psychosocial interventions in Hong Kong. Asian Journal of Psychiatry. 53:102358. https://doi.org/10.1016/j.ajp.2020.102358

Pratama, H., Azman, M.N.A., Kassymova, G.K., Duisenbayeva, S.S. 2020. The Trend in Using Online Meeting Applications for Learning During the Period of Pandemic COVID-19: A Literature Review. Journal of Innovation in Educational and Cultural Research. 1(2):58-68. https://doi.org/10.46843/jiecr.v1i2.15

Qc, I.F. 2020. COVID-19: Fear, quackery, false representations and the law. International Journal of Law and Psychiatry. 72:101611. https://doi.org/10.1016/j.ijlp.2020.101611

Rabi'e, M., Nurhidayati, S. 2018. Pengembangan Model Pembangunan Budaya Antikorupsi Berbasis Keluarga di Kelurahan Prenggan, Kota Yogyakarta. Integritas : Jurnal Antikorupsi. 4(1):145-170. https://doi.org/10.32697/integritas.v4i1.151

Robin, B.R. 2008. Digital storytelling: A powerful technology tool for the 21st century classroom. Theory into Practice. 47(3):220-228. https://doi.org/10.1080/00405840802153916

Siallagan, J., Maryuni, A.E., Sihite, N. 2020. Pelatihan Literasi Baca Tulis dan Numerasi Dasar Bagi Anak-Anak Keluarga Pra-Sejahtera di Wilayah Kaliacai, Kelurahan Vim, Kotaraja Jayapura. Jurnal Pengabdian Papua. 4(3):81-85. https://doi.org/10.31957/.v4i3.1370 
Standish, K. 2020. A coming wave: suicide and gender after COVID-19. Journal of Gender Studies. 30(1):114-118. https://doi.org/10.1080/09589236.2020.1796608

Sumaryati, Suyadi, Hastuti, D. 2019. Pendidikan Antikorupsi dalam Keluarga, Sekolah dan Masyarakat. Yogyakarta: UAD Press

Suyadi. 2020a. Profil pendidikan antikorupsi: Program Pemberdayaan Masyarakat Unggulan Perguruan Tinggi Pada Kelompok Sasaran Taman Kanak-Kanak 'Aisyiyah Bustanul Athfal (TK ABA) Komplek Masjid Perak Desa Antikorupsi Kelurahan Prenggan Kotagede Yogyakarta. Yogyakarta: UAD Press

Suyadi. 2020b. Pendidikan Islam dan Neurosains. Novita, L. (Ed.) (pertama). Jakarta: Kencana

Suyadi. 2019a. Integration of Anti-Corruption Education (PAK) In Islamic Religious Education (PAI) With Neuroscience Approach (Multi-Case Study in Brain Friendly PAUD: I Sleman Kindergarten Yogyakarta). Inferensi : Jurnal Penelitian Sosial Keagamaan. 12(2):307-330. https:// doi.org/10.18326/infsl3.v12i2.307-330

Suyadi. 2019b. Instrumen Observasi Antikorupsi. Yogyakarta: UAD Press

Suyadi. 2018a. Kisah (Storytelling) Pada Pembelajaran Anak Usia Dini Dalam Kajian Neurosains Pendidikan Islam. Jurnal Ilmiah Islam Futura. 18(1):52-74. http://dx.doi.org/10.22373/jiif.v18i1.3130

Suyadi. 2018b. Pendidikan Islam Anak Usia Dini Dalam Perspektif Neurosains: Robotik Akademik Dan Saintifik. Edukasia: $\begin{array}{llll}\text { Jurnal Penelitian } & \text { Pendidikan } & \text { I3(2):231-262. }\end{array}$ https://doi.org/http://dx.doi.org/10.21043/edukasia.v13i2.3255

Suyadi. 2018c. Diferensiasi Otak Laki-laki dan Perempuan Guru Taman Kanak-kanak Aisyiyah Nyai Ahmad Dahlan Yogyakarta: Studi Pendidikan Islam Anak Usia Dini Perspektif Gender dan Neurosains. Sawwa: Jurnal Studi Gender. 13(2):179-202. https://doi.org/10.21580/sa.v13i2.2927

Suyadi. 2016. Teori Pembelajaran Anak usia Dini Dalam Kajian Neurosains. Bandung: Remaja Rosdakarya.

Suyadi. 2014. Manajemen PAUD TPA-KB-TK/RA - Mendirikan, Mengelola dan Mengembangkan PAUD (Pendidikan Anak Usia Dini). Yogyakarta: Pustaka Pelajar

Suyadi, Sumaryati, Hastuti, D., Yusmaliana, D., Rahmah, RD. 2019. Constitutional Piety: The Integration of Anti-Corruption Education into Islamic Religious Learning Based on Neuroscience. J-PAI: Jurnal Pendidikan Agama Islam. 6(1):1-12. https://doi.org/10.18860/jpai.v6i1.8307

Suyadi, Sumaryati. 2020. Inovasi Pendidikan Anak Usia Dini: PAUD Tahfidzulqur'an, PAUD Antikorupsi, PAUD Ramah Otak Berbasis Neurosains, PAUD Siaga Bencana, dan PAUD Adiwiyata. Bandung: Remaja Rosdakarya

Suyadi, Sumaryati, Waharjani, Sukmayadi, T. 2020a. Reading Corner Anti-corruption Literacy in Kindergarten 'Aisyiyah Bustanul Athfal (TK ABA) Perak Mosque Complex, Anti-corruption Village, Prenggan Village, Kotagede Yogyakarta. Jurnal Tarbiyatuna. 11(2):114-127. https://doi.org/10.31603/tarbiyatuna.v11i2.3422

Suyadi, Nuryana, Z., Fauzi, N.A.F. 2020b. The Fiqh of Disaster: The Mitigation of Covid-19 in the perspective of Islamic education-neuroscience. International Journal of Disaster Risk Reduction. International Journal of Disaster Risk Reduction. 51:101848. https://doi.org/10.1016/j.ijdrr.2020.101848

Suyadi, Ulfa, M. 2013. Konsep Dasar PAUD. Bandung: Remaja Rosdakarya

Suyatmoko, W., Nicola, A. 2021. Peluncuran Indeks Persepsi Korupsi 2020: Korupsi dan COVID-19 Memperburuk Kemunduran Demokrasi. Jakarta: Transparency International Indonesia

Thakur, V., Jain, A. 2020. COVID 2019-suicides: A global psychological pandemic. Brain, Behavior, and Immunity. 88:952-953. https://doi.org/10.1016/j.bbi.2020.04.062 
Widiyono, A., Irfana, S., Firdausa, K. 2021. Implementasi Merdeka Belajar melalui Kampus Mengajar Perintis di Sekolah Dasar. Metodik Didaktik: Jurnal Pendidikan Ke-SD-an. 16(2):102-107. https://doi.org/10.17509/md.v16i2.30125

Wulandari, F., Wulandari, F.E., Febryanti, S.A., Dewi, E.P. 2021. Penyusunan Program Sekolah Literasi SD / MI di Kedungbanteng Kecamatan Tanggulangin Sidoarjo. Jurnal ABDINUS: Jurnal Pengabdian Nusantara. 4(2):293-305. https://doi.org/10.29407/ja.v4i2.14327 